FESIEE

Fundación Emilio Soldevilla para la Investigación y Desarrolto de la Economia de la Empresa

\section{Management Letters / Cuadernos de Gestión}

\author{
journal homepage: http://www.ehu.eus/cuadernosdegestion/revista/es/
}

ISSN: 1131-6837 / e-ISSN: 1988-2157

\title{
Modelling e-mail marketing effectiveness - An approach based on the theory of hierarchy-of-effects
}

\section{Modelado de la efectividad en el e-mail marketing - Una aproximación basada en la teoría de jerarquía de efectos}

\author{
Ángel-José Lorente-Páramo ${ }^{\mathrm{a}}$, Ángel Hernández-García*, Julián Chaparro-Peláez \\ a Department of Organization Engineering, Business Administration and Statistics. ETSI de Telecomunicación, Universidad Politécnica de Madrid, Av. Complutense 30, \\ 28040, Madrid (Spain) - ajlorenteparamo@alumnos.upm.es - https://orcid.org/0000-0002-7806-4536 \\ ${ }^{b}$ Department of Organization Engineering, Business Administration and Statistics. ETSI de Telecomunicación, Universidad Politécnica de Madrid, Av. Complutense 30, \\ 28040, Madrid (Spain) - julian.chaparro@upm.es - https://orcid.org/0000-0002-0920-4005
}

* Corresponding author: Department of Organization Engineering, Business Administration and Statistics. ETSI de Telecomunicación, Universidad Politécnica de Madrid, Av. Complutense 30, 28040, Madrid (Spain) - angel.hernandez@upm.es - https://orcid.org/0000-0002-6549-9549

\section{A R T I C L E I N F O}

Received 4 March 2019,

Accepted 26 December 2019

Available online 10 December 2020

DOI: $10.5295 / \mathrm{cdg} .191094 \mathrm{ah}$

JEL CODE: M31, M37

\begin{abstract}
A B S T R A C T
Despite the importance and pervasiveness of e-mail marketing, improving the effectiveness of e-mail marketing programs continues to be a priority for most businesses due to their revenue-generating potential. However, the study of e-mail marketing has been mostly neglected by academic research. More notably, the lack of holistic approaches and conceptual frameworks to tackle this challenge stand in the way of helping companies to better plan and deploy their e-mail marketing strategies and campaigns. This study addresses this issue by proposing a comprehensive model for the study of e-mail marketing effectiveness based on the hierarchy-of-effects theory. The effectiveness model is built by linking the stages of the AIDA (Attention, Interest, Desire, Action) model to the sequence of steps that consumers undergo when they interact with promotional e-mails. This approach allows identifying different partial effectiveness metrics associated with the cognitive, emotional and conative stages, which are later operationalized through key performance indicators with widespread adoption in the industry (open rate, clickthrough rate, retention rate and conversion rate). Thus, attention is linked to open effectiveness, interest is linked both to click effectiveness and subscriber retention effectiveness, and action is linked to conversion effectiveness. The stage of desire is dropped from the model because it usually takes place outside the e-mail marketing process. The study includes a practical illustration of the adequateness of the framework based on data and results from prior studies.
\end{abstract}

Keywords: Digital Marketing, E-mail Marketing, Hierarchy-of-effects, Online Advertising, Effectiveness, AIDA

\section{R E S U M E N}

Pese a la importancia y difusión del e-mail marketing, la mejora de su efectividad continúa siendo una prioridad para la mayoría de anunciantes dado su potencial para la generación de ingresos. Sin embargo, el estudio del e-mail marketing ha sido en gran parte ignorado por la comunidad científica. En concreto, la ausencia de enfoques holísticos y marcos conceptuales de estudio impiden a las compañías mejorar la planificación y ejecución de estrategias de e-mail marketing. Este estudio responde a este problema mediante la propuesta de un modelo general de efectividad de e-mail marketing basado en la teoría de jerarquía de efectos. Así, cada una de las fases del modelo AIDA (Atención, Interés, Deseo, Acción) se vincula a las diversas etapas del proceso secuencial experimentado por los consumidores en su interacción con los correos electrónicos promocionales. Esto permite identificar diferentes métricas parciales de efectividad asociadas a las etapas cognitiva, afectiva y conativa, que a su vez pueden ser operacionalizadas a través de tasas habitualmente utilizadas por la industria (apertura, clic, retención y conversión). En concreto, la etapa de atención queda vinculada a la efectividad de apertura, la etapa de interés a la efectividad de clic y de retención de suscriptores, y la etapa de acción a la efectividad de conversión. El modelo no asocia ninguna métrica a la etapa de deseo dado que ésta ocurre habitualmente fuera del proceso del e-mail marketing. El estudio incluye un ejemplo de la adecuación del modelo conceptual a partir de datos y resultados de estudios previos.

Palabras clave: Marketing Digital, E-mail Marketing, Correo Electrónico, Jerarquía de Efectos, Marketing Interactivo, Efectividad, AIDA 


\section{INTRODUCTION}

Investment in digital marketing has been experiencing a steady increase, with double-digit growth in the past six years (AMA et al. 2017). E-mail marketing, or broadcasting of commercial communications to groups of users via electronic mail (Bawm and Nath 2014), is one of the cornerstones of digital marketing because of its high profitability (Gopal et al. 2006), representing a 14.7 percent of the spending in digital marketing in USA in 2016 (Candent CG 2017).

E-mail marketing is an important source of revenue for companies, with an estimate contribution to $21 \%$ of total sales (eMarketer 2017). Hence, companies are highly interested in optimizing the effectiveness of this marketing channel (eMarketer 2017; Gartner 2017). Improving the effectiveness of e-mail marketing processes is not only beneficial for advertisers, but also for the whole e-mail ecosystem, as consumers will receive more relevant communications, which in turn helps close the virtuous circle between commercial communications and voluntary interaction with the promotional content. Further, permission e-mail marketing, as opposed to unsolicited e-mail or spam, not only serves as a means to drive online traffic or influence impulse purchases, but it is also one of the most effective tools to offer implicit or explicit two-way interaction between retailers and their customers, which in turn can lead to relationship building (Martin et al. 2003; Reimers et al. 2016).

Yet, academic research on this field is scant, and mostly lacks the support of a solid theoretical framework (Sigurdsson et al. 2013); existing research has been limited to the analysis of isolated interactions between consumer and communications, such as opening of e-mails (e.g. Andersson et al. 2014; Balakrishnan and Parekh 2015; Bonfrer and Drèze 2009), following links included in the e-mail (e.g. Rettie and Chittenden 2003; White et al. 2008; Bonfrer and Drèze 2009), unsubscriptions (e.g. Micheaux 2011; Sahni et al. 2018) or conversion to online sales (e.g. Sigurdsson et al. 2013; Wu et al. 2016).

This study aims to go beyond these partial approaches to the study of e-mail marketing by proposing a holistic conceptual framework for the study of e-mail marketing. The proposal of the model is based on the hierarchy-of-effects theory and the AIDA (Attention, Interest, Desire, Action) model, and associates each of the stages of the AIDA model with the different interactions between consumers and the promotional communications, by establishing a link between the stages and "partial effectiveness" metrics, so as to measure effectiveness along the whole process.

The structure of the study is as follows: after the introductory section, Section 2 outlines the hierarchy-of-effects theory and the AIDA model, and details the stages of the AIDA model and their correspondence with effectiveness metrics in e-mail marketing. Section 3 summarizes the main findings from the literature review and proposes the conceptual framework for the study of e-mail marketing effectiveness, which is followed in Section 4 by a critical view and a presentation of the limitations of the AIDA model that might apply to the conceptual framework. Section 5 illustrates the adequateness of the framework with a practical example. Finally, Section 6 presents the main conclusions of the study.

\section{HIERARCHY-OF-EFFECTS THEORY AND THE AIDA MODEL}

Advertising, also known as commercial, promotional or marketing communication, involves mass media-based persuasive communication aimed at informing about a company's products and services and influencing a target audience (Moriarty et al. 2012). The product must satisfy a consumer need (Kotler and Keller 2012), be it utilitarian -i.e. solving a problem or addressing a need- or expressive - associated with a social or aesthetic use- (Maclnnis and Jaworski 1989). Ultimately, the final goal of advertising is revenue generation (Lavidge and Steiner 1961) or, at least, market share growth (Rehman et al. 2014b). Because the three key domains of advertising are perception, education and persuasion (Moriarty 1983), advertisements aim at generating cognitive, emotional and conative responses (Maclnnis and Jaworski 1989; Smith, Chen and Yang 2008) through a persuasive process that can be interpreted as educational (Moriarty 1983; Wijaya 2015).

Despite the lack of consensus on the best approach to measure the outcomes and return on investment of marketing campaigns (Moriarty 1983), there are three main models on the field of advertising effectiveness (Scholten 1996): the hierarchy-of-effects model (Strong 1925; Lavidge and Steiner 1961), the elaboration likelihood model (Petty et al. 1981; Petty et al. 1983; Petty and Cacioppo 1986) and the information processing model (McGuire 1978). Elaboration likelihood and information processing models require the evaluation of factors that are not easily accessible to advertisers, such as consumers' motivations, capability or understanding. In contrast, hierarchy-of-effects models provide a more practical approach by incorporating variables and constructs that are readily available in the online marketing ecosystem (Florès 2014).

When determining the adequacy of hierarchy-of-effects models to the study of e-mail marketing effectiveness, a reasonable starting point is to question whether they relate to the final goal of advertising - most commonly, selling a product(Kotler and Keller 2012). A large majority of marketing actions do not focus on achieving this goal immediately, and rather set up intermediate objectives, such as brand awareness, which brings consumers closer to the company and its products, and facilitates reaching the moment when the commercial transaction finally occurs (Lavidge and Steiner 1961).

The hierarchy-of-effects theory states that the different interactions between consumer and company outline a journey through different stages that get progressively closer to the final goal of the advertiser -i.e. selling the product- (Rehman et al. 2014a). Hierarchy-of-effects-based models provide a systematic approach where every stage is clearly identifiable, enabling the separate analysis of each stage (Bauman et al. 2008). Hierarchy-of-effects-based models present a chain of causal effects along the different stages, facilitating the characterization of consumer behavior at specific moments (Bauman et al. 2008). These stages are not equidistant (Lavidge and Steiner 1961), but they follow a sequential pattern in time (Barry and Howard 1990). 
The AIDA (Attention, Interest, Desire, Action) model is probably the most popular of hierarchy-of-effects-based models. AIDA dates from the late $19^{\text {th }}$ century, after the development of instructions for vendors by E. St. Elmo Lewis. The guidelines identify attention, interest and desire as the sequential stages that a potential customer goes through when purchasing a product, with the later addition of a final stage - action - to reflect the moment of purchase (Strong 1925).

During the following decades, multiple authors added stages to, or removed stages from AIDA to explain consumer behavior in more detail or to adapt the model to new technological contexts. Table 1 summarizes the different modifications of the AIDA model (Barry and Howard 1990; Wijaya 2015), even though some scholars sustain that the contribution of each variation of the model is marginal (Barry and Howard 1990).

Table 1

Summary of main hierarchy-of-effects models throughout the twentieth century

\begin{tabular}{cll}
\hline Year & \multicolumn{1}{c}{ Model } & \multicolumn{1}{c}{ Author } \\
\hline 1898 & AID: Attention, Interest, Desire & E. St Elmo Lewis \\
1900 & $\begin{array}{l}\text { AIDA: Attention, Interest, Desire, } \\
\text { Action }\end{array}$ & E. St Elmo Lewis \\
\end{tabular}

1910 AICA: Attention, Interest, Conviction, Action

1911 AIDAS: Attention, Interest, Desire, Action, Satisfaction

1915 AICCA: Attention, Interest, Confidence, Conviction, Action

1921 AIDCA: Attention, Interest, Desire, Caution, Action

1921 AIDCA: Attention, Interest, Desire, Harry D. Kitson Conviction, Action

1922 AUA: Attention, Interest, Judgement, Alexander Osbom Action

1940 AIDCA: Attention, Interest, Desire, Clyde Bedell Conviction, Action

1956 AIDMA: Attention, Interest, Desire, Merrill Devoe Memory, Action

Source: Adapted from Barry and Howard (1990) and Wijaya (2015).

In 1961 two new hierarchy-of-effects models were proposed, immediately capturing the attention of advertisers and significantly influencing future proposals (Kotler and Keller 2012). The first of them was Lavidge and Steiner's (1961) model, considered the first to introduce a psychological aspect on hierarchy-of-effects models; the model explains the interaction between consumer and advertising as a sequential process comprising three stages: cognitive (awareness and knowledge), affective (liking and preference) and conative (conviction and purchase), a structure also incorporated in subsequent proposals (Barry and Howard 1990; Smith et al. 2008). The second model is DAGMAR (Defining Advertising Goals for Measured Advertising Results; Colley 1961). The DAGMAR model posits that communication effects are the foundation of advertising objectives, suggesting that consumers go through the stages of awareness, comprehension, conviction and action during their path to purchase (Belch and Belch 2003). The same as AIDA, these models fall into the category of persuasive hierarchy models that follow the cognitive-affective-behavior sequence (Vakratsas and Ambler 1999).

Despite the popularity of these two models and the apparent simplicity of the AIDA model, AIDA has prevailed after every iteration and transformation of media in the last decades; it is the most representative (Huey 1999; Florès 2014; Rehman et al. 2014a) and most widely applied (Diehl and Terlutter 2003) hierarchy-of-effects model, and is still considered an appropriate tool to study effectiveness in digital marketing (Ashcroft and Hoey 2001). The following subsections describe each of the stages, establishing the correspondence between stages of the AIDA model and metrics of e-mail marketing effectiveness.

\subsection{Attention}

Attention is a key element in the application of perceptual psychology to the study of advertising effectiveness (Moriarty 1983). Attention is a limited cognitive resource (Kahneman 1973) that an individual may devote, in different degrees, to an object (Maclnnis and Jaworski 1989). In a context characterized by the saturation of promotional messages, with every individual being exposed to between 1000 and 5000 daily commercial communications (Martí Parreño et al. 2013), attention has become a most-wanted resource because the first objective of every marketing campaign is to attract the attention of consumers.

Attention refers to "the act or state of applying the mind to something" (Merriam-Webster 2011). Even though attention has an involuntary component, individuals generally make conscious decisions about which stimuli they give preference to - selective attention - after registering, storing and processing all perceptual information (Kahneman 1973). Therefore, it is necessary for advertisers to offer consumers an initial stimulus that, after being processed, is considered worthy of attention. A regular practice to capture attention involves the incorporation of original elements that depart from standard communication (Yoo et al. 2004); for example, the use of different advertising sizes, colors or positions within the communication media is a common practice among companies to influence perceptual selection and ensure that the promotional message does not get lost in the "vast sea of stimuli" that consumers have to process (Solomon and Rabolt 2009). Hence, the study of attention should focus on the very first moment when consumers interact with the promotional content because when that interaction is not positive, the communication will be interrupted and the promotional message will not be processed in its entirety.

In e-mail marketing, the typical moment users decide whether to pay attention to an e-mail occurs when they check their inbox. Even though the widespread use of mobile technologies and apps allow recipients to make this decision when 
they receive a notification in their smartphone, this study refers to the inbox in general as the place where that first interaction occurs.

Despite the difficulty of measuring attention in other contexts (Florès 2014), in e-mail marketing campaigns the process requires an action from the consumer - opening the e-mailfor actual content consumption to happen. Thus, it is possible to detect and quantify the number of users that pay attention to every e-mail by using the open rate metric, defined as the ratio between opened and sent e-mails (Andersson et al. 2014). Therefore, there is a correspondence between open rate - or the ability to have the promotional e-mails opened by subscribed users - and the ability to situate the consumer in the first stage of the AIDA model (Arnold 2008). This correspondence is consistent with the application of the AIDA model to the study of effectiveness in other marketing media, such as web banners, where the first interaction with the ad belongs in the attention stage (Goodrich 2011).

\subsection{Interest}

The second stage of AIDA is interest, or "a feeling that accompanies or causes special attention to an object or class of object" (Merriam-Webster 2011). From a psychological perspective, interest comprises both cognitive (Wijaya 2015) and affective (Hassan et al. 2015; Wijaya 2015) elements, and therefore it refers to the point where sensory perceptions start to operate at attitudinal and opinion-forming levels.

Capturing users' attention ensures that the communication between advertiser and consumer extends beyond the mere contact, but keeping the interaction alive requires progressing to the interest stage. For users to reach this stage, it is necessary to have certain knowledge about the benefits of the product (Hassan et al. 2015), which requires that they have enough information about the campaign to form an opinion ( $\mathrm{Su}$ et al. 2016). Thus, interest is not as immediate as attention. Interest entails a longer interaction to ensure the adequate communication of the message - or, at least, of the outline of the message. Fostering interest requires that the recipient perceives the message as original content (Hassan et al. 2015) to avoid perceptual adaptation (Solomon et al. 2013), which refers to the action of discarding or ignoring a message due to self-perception of previous exposure to the message and the subsequent consideration that the message does not contain any new information. It is therefore necessary to find a balance between simplicity and complexity of the message (Bruner and Kumar 2000) that creates a perception of novelty but also allows the individual to easily process the information.

One of the consequences of interest is its active expression (Ghirvu 2013), which manifests as the desire for more information about the object that arouses the interest (Ashcroft and Hoey 2001). It is natural then that, the same way that attention is an entry point to interest, interest may act as an introductory stage toward a deeper relation between the user and the company.

In online contexts, there is a strong relation between interest and interactive media (Hassan et al. 2015). In general, websites are the most effective medium to drive consumers' interest (Lagrosen 2005) because of their higher flexibility and, even though websites and e-mails share a common markup language, consumers perceive a clear difference between both (Cases et al. 2010). Because the presentation of information that may lead users into the interest stage is critical for e-mail marketing to be effective, it is not possible to reach this stage unless the recipient opens the e-mail.

When the e-mail arrives at the inbox, the sender and subject of the e-mail are the only information available, and that information alone may not be enough for an individual to form an opinion. Opening an e-mail defines the boundary between attention and interest, but the most natural action an individual performs after reading an e-mail -i.e. visiting any link included in the promotional communication - is the active expression of interest. It is possible then to establish a correspondence between the expression of interest and click effectiveness, or the ability to get subscribed users to click a promotional link in the e-mail (Florès 2014). Click effectiveness can be measured using the click-through rate (CTR), defined as the ratio between clicks and e-mails sent (Arnold 2008).

Additionally, it is worth noting that when the recipient does not consider an e-mail interesting, he or she might want to avoid future communications (Micheaux 2011). Consequently, it is possible to establish a relation between the ability to raise interest in the potential customer and subscriber retention effectiveness, which refers to the ability to keep subscribed users' information in the company database. Subscriber retention effectiveness can be operationalized through unsubscription rate, most commonly known as retention rate, measured as the ratio between users that ask to be removed from the database and the total number of recipients (Mullen and Daniels 2011).

\subsection{Desire}

The next stage in AIDA is desire, or "the conscious impulse toward something that promises enjoyment or satisfaction in its attainment" (Merriam-Webster 2011). From a marketing perspective, desire reflects an aspiration to the possession of the product or service being advertised (Hassan et al. 2015). Desire involves an emotional state where the consumer believes in the truth of the promotional message (Wijaya 2015), aspires to, and even dreams about the product (Lin and Huang 2006), feeling an inclination toward purchasing it (Rehman et al. 2014a). The stronger the feeling of desire, the higher the purchasing intention and, consequently, the higher the chances that the consumer reaches the next stage (Mihart 2012).

The state of desire is usually associated with feelings toward the brand (Cramphorn 2006), and thus reaching this state may vary depending on the previous interactions between the consumer and the company. Therefore, a careful definition of the target audience of the marketing campaign is key to improve effectiveness ( $\mathrm{Su}$ et al. 2016) because it allows marketers to address specific needs of each market segment depending on their perception of the company or brand.

Desire, which has been replaced in some variations of the framework by concepts like conviction or confidence (Strong 1925), is a controversial state within the AIDA model. The 
main reason of this controversy is that the transition from interest to desire is extremely difficult to identify and measure (Ghirvu 2013) because the frontier between predisposition and aspiration is blurry. There is no doubt that e-mail promotional messages may have influence on this transition, but the crossing point between interest and desire often happens outside of the e-mail marketing process.

Most often, once the communication has effectively raised interest, the consumer will probably begin to interact with multiple channels and sources. Therefore, measurement of desire might involve the number of web pages per browsing session or the number of visits to the web page by unique visitors (Florès 2014). However, consumers are very likely to visit similar web pages, look for ratings or seek advice from other users in different web pages and social networks. In this typical scenario, the assessment of the individual contribution of each source or channel makes it even more difficult to quantitatively measure desire, and measuring only user hits to the e-mail target link would result in a largely biased perception about consumers' desire and actual behavior. Contrarily to conversion effectiveness, which will be detailed in the next subsection, it is nearly impossible in this situation to elaborate an unambiguous coding scheme to solve this problem. Therefore, the model proposed in this study does not link this stage to any action or measure.

\subsection{Action}

The last stage of the AIDA model is action, or "the accomplishment of a thing usually over a period of time, in stages, or with the possibility of repetition" (Merriam-Webster 2011). Every marketing campaign pursues some goal, such as completing a form or consumption of information. Most commonly, the main objective is to sell a product, and therefore the action is generally associated with the purchase of the product (Rehman et al. 2014a). From a psychological perspective, action develops at a behavioral level (Wijaya 2015) and reflects a successful completion of the cognitive process designed by the advertiser (Ghirvu 2013). Furthermore, it is very easy to verify due to its binary nature: either the product is sold or not.

As consumers go through the different stages of AIDA, the effort required to get to the following stage increases (Bauman et al. 2008) because traversing to the next stage demands a higher psychological or economic commitment. Consequently, the difficulty to persuade the consumer to get to each subsequent stage of the model increases (Lavidge and Steiner 1961). Therefore, clearly showing the benefits of the product to the consumer and reducing the effort required to complete the desired behavior is essential to facilitate the transition to action (Wilson et al. 2015).

The digital nature of e-mail marketing and e-commerce facilitates the measurement of action. Action is directly connected to conversion effectiveness, or "the ability to get subscribed users to perform the desired action or outcome for the campaign". Again, subscribers may interact with additional channels and sources before performing the desired action, which makes it difficult to determine the individual contribution of each of them (Jordan et al. 2011). Therefore, attri- bution models play a fundamental role in the measurement of action. However, and contrarily to the case of desire, in e-mail marketing it is possible to measure the number of visitors who come from a communication received via e-mail and purchase a product, by setting specific parameters in the link included in the e-mail or from the information stored in a cookie. Hence, it is possible to define a specific measure known as conversion rate (CR) that represents the ratio between the users who perform the action and the total number of visitors from the e-mail communication (Smart and Cappel 2003).

\section{AIDA AND THE MEASUREMENT OF E-MAIL MARKETING EFFECTIVENESS}

There is a consensus that AIDA offers an adequate framework to model the measurement of the goals of most online communications: to stimulate consumption using attractive content (Lagrosen 2005). As such, its application to digital marketing processes does not require any particular modification (Ashcroft and Hoey 2001), and digital giants like Google already incorporate AIDA in their product design processes (Florès 2014). AIDA has been successfully applied to assess the effectiveness of different online communication channels like mobile ads (Rehman et al. 2014b; Su et al. 2016), social networks (Lukka and James 2014; Wood and Burkhalter 2014; Hassan et al. 2015), online gaming positioning (Ghirvu 2013), web pages (Lagrosen 2005) or blogs (Lin and Huang 2006).

As seen in section 2, there is a correspondence between the stages of AIDA, the different activities of the e-mail marketing process and different e-mail marketing metrics (Table 2 and Fig. 1). For instance, the three main steps of e-mail marketing - getting the recipient to open the e-mail, maintaining the interest of the recipient, and persuading him or her to perform the desired action- (Theerthaana and Sharad 2014) have a direct correspondence with the attention, interest and action stages of AIDA, respectively. Further, previous models used in e-mail marketing research share a procedural view that closely resembles the AIDA model (Rettie and Chittenden 2003; Bawm and Nath 2014; Lim et al. 2016).

Table 2

Conceptual framework

\begin{tabular}{llll}
\hline Consumer action & AIDA stage & \multicolumn{1}{c}{$\begin{array}{c}\text { Effectiveness } \\
\text { metric }\end{array}$} & $\begin{array}{c}\text { Measurement } \\
\text { variable }\end{array}$ \\
\hline $\begin{array}{l}\text { Opening an } \\
\text { e-mail }\end{array}$ & Attention & $\begin{array}{l}\text { Opening } \\
\text { effectiveness }\end{array}$ & Open rate \\
Clicking a link & Interest & $\begin{array}{l}\text { Click } \\
\text { effectiveness }\end{array}$ & $\begin{array}{l}\text { Click-through } \\
\text { rate }\end{array}$ \\
Unsubscribing & Interest & $\begin{array}{l}\text { Retention } \\
\text { effectiveness }\end{array}$ & Retention rate \\
$\begin{array}{l}\text { Purchasing a } \\
\text { product }\end{array}$ & Action & $\begin{array}{l}\text { Conversion } \\
\text { effectiveness }\end{array}$ & Conversion rate \\
\hline
\end{tabular}

Source: authors. 


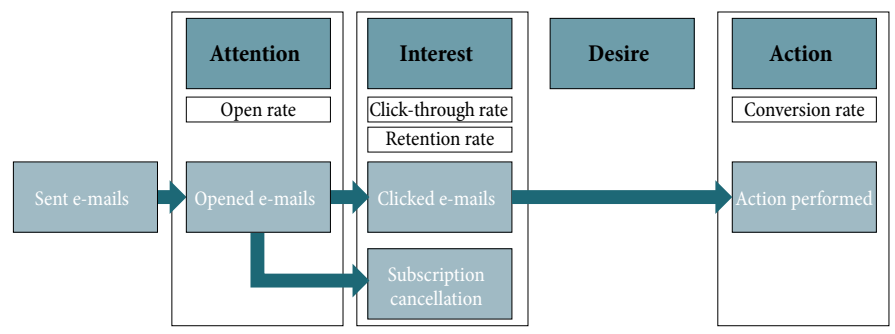

Figure 1

Graphical representation of the general conceptual framework showing the different stages of the AIDA model, the metrics used during each stage and the actions performed by consumers

Source: authors.

Section 2 also highlights the close similarity between the different e-mail activities and the AIDA stages, helping overcome one of the most notable limitations of the models based on the hierarchy-of-effects theory: how to characterize the consumer journey through the different stages and how to identify and measure the exact moment the consumer reaches a stage (Lavidge and Steiner 1961).

The model proposed in this study does however incorporate a slight modification to AIDA by omitting desire, as mentioned and justified in section 2.3. Nonetheless, this approach is still consistent with the division of hierarchy-of-effects models in cognitive, affective and conative stages (Lavidge and Steiner 1961).

\section{A CRITICAL VIEW OF THE AIDA MODEL}

Even though the use and application of the AIDA model in marketing and consumer behavior research is a regular practice, it is not exempt from criticism. Most critiques focus on some assumptions of the AIDA model, such as the idea that all the different stages are sequentially connected (Moriarty 1983). AIDA assumes that the decisions a consumer makes are rational (Moriarty 1983; Barnham 2008) and that the consumer goes through a linear and sequential process composed of discrete interactions, omitting the inter-relation between cognitive and emotional stages (Barry and Howard 1990; Huey 1999).

Additionally, AIDA does not incorporate some elements typically used in consumer behavior research, such as information processing (Maclnnis and Jaworski 1989) or brand loyalty (Kotler and Keller 2012). Therefore, AIDA considers consumers as passive subjects who react to the provision of information, as opposed to treating consumers as proactive entities that use the information available to make decisions (Huey 1999).

Despite these limitations and the different modifications of the models shown in Table 1, the main principles of AIDA remain intact and are still relevant (Hassan et al. 2015), and the sequential stages have the additional advantage of making it easier to identify the contribution of each individual and independent interaction (Kojima et al. 2010). Additionally, AIDA facilitates the clear definition of the most relevant variables to explain consumers' reactions (Strong 1925) and the delimitation of specific activities and actions makes it a valuable planning tool (Barry and Howard 1990).
From the above, the main advantage and disadvantage of the AIDA model probably lies its simplicity. This simplicity involves making some assumptions that should be further justified on a per case basis, but it also confers a practical and operational nature that makes it especially useful for research.

\section{PRACTICAL EXAMPLE}

This section illustrates the adequateness of the framework proposed in this study to measure e-mail marketing effectiveness using data from a real campaign. To do so, the example examines the metrics used in Sahni et al.'s (2018) study, focused on e-mail marketing campaign performance, and compares them with the conceptual framework presented in Section 3. Sahni et al. (2018) analyze the results of a marketing campaign whose objective is to commercialize training courses by sending a promotional e-mail to a subscriber database with the objective of generating sales leads. The results corresponding to the control group in their experimental setting $1^{1}$ (summarized in Table 3 ) and the industry averages reported by GetResponse (2018) are used as baseline for our discussion.

Table 3

Promotional e-mail results

\begin{tabular}{lccc}
\hline \multicolumn{1}{c}{ Metric } & Mean (\%) & Standard error (\%) & $\begin{array}{c}\text { Number of } \\
\text { observations }\end{array}$ \\
\hline Opened / Sent & 9.05 & $(0.16)$ & 34766 \\
Unsubscribed / Sent & 1.2 & $(0.05)$ & 34766 \\
Leads / Opened & 4.29 & $(0.36)$ & 34766 \\
\hline
\end{tabular}

Source: control group, experiment 1 (Sahni, Wheeler and Chintagunta 2018)

Two of the three metrics reported in Sahni et al. (2018) can be directly related to the stages described in Section 2 and the framework proposed in Section 3. The opened-sent ratio, or open rate (attention stage), of $9.05 \%$ is significantly lower than the average of $31.59 \%$ in the education industry (GetResponse 2018). Consequently, the campaign may not be considered effective in capturing the attention of recipients. The subject line is one of the key influencing factors in the attention stage (Micheaux 2011); in this particular case, the text used on the subject line is a descriptive summary of the content, but lacks some of the characteristics that may improve the chances of capturing consumers' attention, such as being entertaining (Lu et al. 2007) or the inclusion of personalized elements in the subject line, as the results of the treatment group in Sahni et al.'s (2018) study shows ${ }^{2}$.

Similarly, the unsubscribed-sent ratio, or subscription cancellation rate, is almost five times higher than the $0.25 \%$ average in the industry (GetResponse 2018), pointing to a lower perfor-

\footnotetext{
1 The treatment condition of Sahni et al. (2018) consists on the inclusion of the recipient's name in the subject line.

${ }^{2}$ Shani et al. (2018) found a 20 percent increase in open rates when including the name of the recipient in the subject line.
} 
mance on the interest stage; a possible explanation to this low effectiveness might be the lack of economic incentives of the e-mail, as these elements have been found to improve users' interest in promotional communications (Baggott 2011).

Finally, the leads-sent ratio used in the study may not be considered either a click-through rate or a conversion rate, as it blends information both from the interest stage (clicked-sent) and from the action stage (leads-clicked); while the leads-sent ratio is a relatively common metric in e-mail marketing, it does not provide accurate information about performance of the interest and action stages separately. Had the results been reported as per the model proposed in this study, it would have been possible to differentiate the performance of both stages. The usefulness of this separation of effectiveness measures for each stage lies in that performance in each stage may be driven by different influencing factors. For instance, the length of the e-mail and the number of links included in the e-mail may affect effectiveness in the interest stage (Chittenden and Rettie 2003) whereas other elements, such as the inclusion of personalized elements - e.g. the inclusion of the name of the recipient in the e-mail- or segmentation of the subscriber database may be most relevant in the action stage (Jackson and DeCormier 1999; Theerthaana and Sharad 2014). A good example of the usefulness of this separation between stages can be found in Sigurdsson et al. (2015), who observed higher open rates and click-through rates (attention and interest stages) using utilitarian and informational stimuli than using only utilitarian stimuli among consumers who were initially not interested in the product, but lower conversion rates, or sales (action stage), which was the primary objective of the e-mail marketing campaign under study.

\section{CONCLUSIONS}

From Section 2, the definition of partial effectiveness metrics in e-mail marketing fits with the process and the different stages of the AIDA model, offering an adequate and comprehensive conceptual framework for the study of e-mail marketing effectiveness (summarized in Table 2 and Fig. 1). The different rates or metrics used to quantify and measure effectiveness in each stage give a precise and objective assessment of the level of success of an e-mail marketing campaign along the whole process. The study also allows us to provide a precise definition of e-mail marketing effectiveness, understood as "the ability to keep subscribed users information stored in the company's database and get them to open a promotional e-mail, visit a link to the corporate web or online shop, and perform a specific action that matches the objective of the e-mail marketing campaign". This definition combines all the different elements of the process and incorporates the linear and aggregate nature of opening, click and conversion.

The conceptual framework presented in this research sets the basis for a systematic study of e-mail marketing effectiveness, by linking the hierarchy-of-effects theory and metrics used by companies and marketing practitioners. This theoretical contribution closes the current gap between academic research and practice, and provides scholars with a starting point to further investigate this relevant phenomenon. Further, the conceptual study uses a practical example to revise recent research on e-mail marketing and demonstrate the adequateness of the proposed framework.

Future research could use the conceptual framework from this study to examine different variables affecting the actions in each stage - quantified by the different metrics associated with them-, such as message length or content, which in turn would provide companies with valuable information about how to increase the effectiveness of their marketing campaigns. Upon the results from such studies, further research could focus on studying the effect of cultural variables that could help companies developing world-wide e-mail marketing campaigns.

\section{REFERENCES}

AMA, Deloitte and Duke University, 2017. The CMO Survey. Available at: https://cmosurvey.org/wp-content/uploads/sites/15/2017/08/The CMO_Survey-Highlights_and_Insights-Aug-2017.pdf (Accessed: 22 January 2018).

Andersson, M., Fredriksson, M. and Berndt, A., 2014. Open or delete: decision-makers attitudes towards e-mail marketing messages. Advances in Social Sciences Research Journal, 1(3), 133-144. doi: 10.14738/assrj.13.201.

Arnold, J., 2008. Email marketing for dummies. $2^{\text {nd }}$ ed. Hoboken, NJ: Wiley Publishing, Inc.

Ashcroft, L. and Hoey, C., 2001. PR, marketing and the Internet: implications for information professionals. Library Management. MCB UP Ltd, 22(1/2), 68-74. doi: 10.1108/01435120110358952.

Balakrishnan, R. and Parekh, R., 2015. Learning to predict subject-line opens for large-scale email marketing. Proceedings of the 2014 IEEE International Conference on Big Data, IEEE Big Data 2014. Washington, DC: IEEE, 57-584. doi: 10.1109/BigData.2014.7004277.

Barnham, C., 2008. Instantiation - Reframing brand communication. International Journal of Market Research, 50(2), 203-220. doi: $10.1177 / 147078530805000205$

Barry, T.E. and Howard, D.J., 1990. A review and critique of the hierarchy of effects in advertising. International Journal of Advertising, 9(2), 121-135. doi: 10.1080/02650487.1990.11107138.

Bauman, A., Bowles, H.R., Huhman, M., Heitzler, C.D., Owen, N., Smith, B.J. and Reger-Nash, B., 2008. Testing a Hierarchy-of-Effects Model. Pathways from Awareness to Outcomes in the VERB Campaign 2002-2003. American Journal of Preventive Medicine. Elsevier, 34(6 SUPPL.), S249-S256. doi: 10.1016/j.amepre.2008.03.015.

Bawm, Z.L. and Nath, R.P.D., 2014. A Conceptual Model for effective email marketing. in 2014 17th International Conference on Computer and Information Technology (ICCIT). Dhaka: IEEE, 250-256. doi: 10.1109/ICCITechn.2014.7073103.

Bonfrer, A. and Drèze, X., 2009. Real-Time Evaluation of E-mail Campaign Performance. Marketing Science, 28(2), 251-263. doi: 10.1287/ mksc. 1080.0393 .

Bruner, G.C. and Kumar, A., 2000. Web commercials and advertising hierarchy-of-effects. Journal of Advertising Research, 40(1-2), 35-42. doi: 10.2501/JAR-40-1-2-35-42.

Candent CG, 2017. 2017 Marketing Spend Study. Available at: http://cadentcg.com/wp-content/uploads/2017-Marketing-Spending-Study. pdf (Accessed: 22 January 2018).

Cases, A.S., Fournier, C., Dubois, P.L. and Tanner, J.F., 2010. Web Site spill over to email campaigns: The role of privacy, trust and shoppers' attitudes. Journal of Business Research, 63(9-10), 993-999. doi: 10.1016/j.jbusres.2009.02.028. 
Cramphorn, S., 2006. How to use advertising to build brands-In search of the philosopher's stone. International Journal of Market Research, 48(3), 255-276. doi: 10.1177/147078530604800303.

Diehl, D., and Terlutter, R., 2003. The Role of Lifestyle and Personality in Explaining Attitude to the Ad. In: Flemming Hansen, Lars Bech Christensen (eds), Branding and Advertising, 306-331. Copenhagen: Copenhagen Business School Press.

eMarketer, 2017. Email Marketing Benchmarks 2017. Available at: https://www.emarketer.com/Report/Email-Marketing-Benchmarks-2017-Metrics-Steady-Data-Creates-Better-Context-Relevance/2002096 (Accessed: 4 June 2018).

Florès, L., 2014. How to Measure Digital Marketing. $1^{\text {st }}$ ed. London: Palgrave Macmillan UK. doi: 10.1057/9781137340696.

Gartner, 2017. Market Guide for Email Marketing. Available at: https:// www.gartner.com/doc/3621346/market-guide-email-marketing (Accessed: 3 February 2018).

GetResponse, 2018. Email Marketing Benchmarks. Available at: https:// www.getresponse.com/resources/reports/email-marketing-benchmarks.html (Accessed: 3 February 2018).

Ghirvu, A.I., 2013. The AIDA model for Advergames. USV Annals of Economics and Public Administration, 13(1), 90-98.

Goodrich, K., 2011. Anarchy of effects? Exploring attention to online advertising and multiple outcomes. Psychology and Marketing, 28(4), 417-440. doi: 10.1002/mar.20371.

Gopal, R.D., Tripathi, A.K. and Walter, Z.D., 2006. Economics of first-contact email advertising. Decision Support Systems, 42(3), 1366-1382. doi: 10.1016/j.dss.2005.11.004.

Hassan, S., Zaleha, S., Nadzim, A. and Shiratuddin, N., 2015. Strategic Use of Social Media for Small Business Based on the AIDA Model. Procedia - Social and Behavioral Sciences, 172, 262-269. doi: 10.1016/j.sbspro.2015.01.363.

Huey, B., 1999. Advertisings Double Helix: A Proposed New Process Model. Journal of Advertising Research, 39(May), 43-51.

Jordan, P., Mahdian, M., Vassilvitskii, S. and Vee, E., 2011. The multiple attribution problem in pay-per-conversion advertising. in Lecture Notes in Computer Science (including subseries Lecture Notes in Artificial Intelligence and Lecture Notes in Bioinformatics). Springer Berlin Heidelberg, 31-43. doi: 10.1007/978-3-64224829-0_5.

Kahneman, D., 1973. Attention and effort. $1^{\text {st }}$ ed. Englewood Cliffs, NJ: Prentice Hall.

Kojima, T., Kimura, T., Yamaji, M. and Amasaka, K., 2010. Proposal and Development of the Direct Mail Method PMCI-DM For Effectively Attracting Customers. International Journal of Management \& Information Systems, 14(5), 15-22. doi: 10.19030/ijmis.v14i5.9.

Kotler, P. and Keller, K.L., 2012. Marketing Management. 14th edn. Boston, MA: Prentice Hall.

Lagrosen, S., 2005. Effects of the internet on the marketing communication of service companies. Journal of Services Marketing, 19(2), 63-69. doi: 10.1108/08876040510591376.

Lavidge, R.J. and Steiner, G.A., 1961. A Model for Predictive Measurements of Advertising Effectiveness. Journal of Marketing, 25(6), 59. doi: $10.2307 / 1248516$.

Lim, K.H., Lim, E.-P., Jiang, B. and Achananuparp, P., 2016. Using Online Controlled Experiments to Examine Authority Effects on User Behavior in Email Campaigns. in Proceedings of the 27th ACM Conference on Hypertext and Social Media. Halifax: ACM, 255-260. doi: $10.1145 / 2914586.2914619$.

Lin, Y.-S. and Huang, J.-Y., 2006. Internet blogs as a tourism marketing medium: A case study. Journal of Business Research, 59(10-11), 1201-1205. doi: 10.1016/j.jbusres.2005.11.005.

Lukka, V. and James, P.T.J., 2014. Attitudes toward Facebook advertising. Journal of Management and Marketing Research, 14, 1-26.
Maclnnis, D.J. and Jaworski, B.J., 1989. Information Processing from Advertisements: Toward an Integrative Framework. Journal of Marketing, 1-23. doi: 10.2307/1251376.

Martí Parreño, J., Cabrera García-Ochoa, Y. and Aldás Manzano, J., 2013. La publicidad actual: retos y oportunidades. Pensar la Publicidad. Revista Internacional de Investigaciones Publicitarias, 6(2), 327-343. doi: 10.5209/rev_PEPU.2012.v6.n2.41219.

Martin, B., Van Durme, J., Raulas, M. and Merisavo, M., 2003. Email advertising: exploratory insights from Finland. Journal of Advertising Research, 43(3), 293-300. doi: 10.1017/S0021849903030265.

McGuire, W.J., 1978. An information-processing model of advertising effectiveness. in Davis, H. L. and Silk, A. J. (eds) Behavioral and Management Science in Marketing. New York: Ronald Press, 156-180.

Merriam-Webster, 2011. Dictionary.

Micheaux, A.L., 2011. Managing e-mail Advertising Frequency from the Consumer Perspective. Journal of Advertising, 40(4), 45-66. doi: 10.2753/JOA0091-3367400404.

Mihart, C., 2012. Modelling the Influence of Integrated Marketing Communication on Consumer Behaviour: An Approach based on Hierarchy of Effects Concept. Procedia - Social and Behavioral Sciences, 62, 975-980. doi: 10.1016/j.sbspro.2012.09.166.

Moriarty, S., 1983. Beyond the Hierarchy of Effects: A Conceptual Framework. Current Issues and Research in Advertising. Taylor \& Francis Group, 6(1), 45-55.

Moriarty, S., Mitchell, N.D., Wells, W.D., Crawford, R., Brennan, L. and Spence-Stone, R., 2012. Advertising \& IMC: Principles and practice. Boston, MA: Prentice Hall.

Mullen, J. and Daniels, D., 2011. Email marketing: an hour a day. $1^{\text {st }}$ ed. Indianapolis, IN: John Wiley \& Sons.

Petty, R.E. and Cacioppo, J.T., 1986. The elaboration likelihood model of persuasion. Advances in experimental social psychology, 19, 123-205. doi: 10.1007/978-1-4612-4964-1_1.

Petty, R.E., Cacioppo, J.T. and Goldman, R., 1981. Personal Involvement as a Determinant of Argument-Based Persuasion. Journal of Personality and Social Psychology, 41(5), 847-855.

Petty, R.E., Cacioppo, J.T. and Schumann, D., 1983. Central and Peripheral Routes to Advertising Effectiveness: The Moderating Role of The Moderating Role of Involvement. Journal of Consumer Research, 10(2), 135-146. doi: 10.1086/208954.

Rehman, F.U., Javed, F., Nawaz, T., Ahmed, I. and Hyder, S., 2014a. Some Insights in the Historical Prospective of Hierarchy of Effects Model: A Short Review. Information Management and Business Review, 6(6), 301-308.

Rehman, F.U., Nawaz, T., Ilyas, M. and Hyder, S., 2014b. A Comparative Analysis of Mobile and Email Marketing Using AIDA Model. Journal of Basic and Applied Scientific Research, 4(6), 38-49.

Reimers, V., Chao, C-W., Gorman, S., 2016. Permission email marketing and its influence on online shopping. Asia Pacific Journal of Marketing and Logistics, 28(2), 308-322. doi: 10.1108/APJML-03-2015-0037.

Rettie, R. and Chittenden, L., 2003. Email Marketing: Success Factors. Kingston Business School - Occasional Paper Series.

Sahni, N.S., Wheeler, S.C. and Chintagunta, P., 2018. Personalization in Email Marketing: The Role of Non-Informative Advertising Content. Marketing Science, 37(2), 236-258. doi: 10.1287/mksc.2017.1066.

Scholten, M., 1996. Lost and found: The information-processing model of advertising effectiveness. Journal of Business Research, 37(2), 97 104. doi: 10.1016/0148-2963(96)00058-6.

Sigurdsson, V., Menon, R.G.V., Sigurdarson, J.P., Kristjansson, J.S. and Foxall, G.R., 2013. A test of the behavioral perspective model in the context of an e-mail marketing experiment. The Psychological Record, 63(2), 295-308. doi: 10.11133/j.tpr.2013.63.2.005.

Sigurdsson, V., Hinriksson, H., and Menon, R.G.V., 2015. Operant Behavioral Economics for E-mail Marketing: An Experiment Based on 
the Behavioral Perspective Model Testing the Effectiveness of Motivational Operation, Utilitarian and Informational Stimuli. Managerial and Decision Economics, 37(4-5), 337-344. doi:10.1002/mde.2725.

Smart, K. and Cappel, J., 2003. Assessing the response to and success of email marketing promotions. Issues in Information Systems, 4(1), 309-315.

Smith, R.E., Chen, J. and Yang, X., 2008. The Impact of Advertising Creativity on the Hierarchy of Effects. Journal of Advertising, 37(4), 47-61. doi: 10.2753/JOA0091-3367370404.

Solomon, M., Bamossy, G., Askegaard, S. and Hogg, M., 2013. Consumer behaviour: a European perspective. $5^{\text {th }}$ ed. Harlow: Pearson.

Solomon, M.R. and Rabolt, N.J., 2009. Consumer behavior: in fashion. $2^{\text {nd }}$ ed. Boston, MA: Prentice Hall.

Strong, E.K.J., 1925. Theories of selling. Journal of Applied Psychology, 9(1), 75-86. doi: 10.1037/h0070123.

$\mathrm{Su}$, K.W., Huang, P.H., Chen, P.H. and Li, Y.T., 2016. The impact of formats and interactive modes on the effectiveness of mobile advertisements. Journal of Ambient Intelligence and Humanized Computing. Springer Berlin Heidelberg, 7(6), 817-827. doi: 10.1007/s12652-016-0343-x.

Theerthaana, P. and Sharad, S., 2014. A Study to Improve the Response in Email Campaigning by Comparing Data Mining Segmentation Approaches in Aditi Technologies. International journal of management and business research, 4(4), 273-293.
Vakratsas, D., and Ambler, T., 1999. How Advertising Works: What Do We Really Know? Journal of Marketing, 63(1), 26-43. doi: 10.2307/1251999

White, T.B., Zahay, D.L., Thorbjornsen, H. and Shavitt, S., 2008. Getting too personal: Reactance to highly personalized email solicitations. Marketing Letters. Springer US, 19(1), 39-50. doi: 10.1007/s11002-007-9027-9.

Wijaya, B.S., 2015. The Development of Hierarchy of Effects Model in Advertising. International Research Journal of Business Studies, 5(1), 73-85. doi: 10.21632/irjbs.5.1.73-85.

Wilson, E.V., Hall-Phillips, A. and Djamasbi, S., 2015. Cognitive predictors of consumers intention to comply with social marketing email appeals. Computers in Human Behavior, 52, 307-314. doi: $10.1016 / j . c h b .2015 .06 .014$.

Wood, N.T. and Burkhalter, J.N., 2014. Tweet this, not that: A comparison between brand promotions in microblogging environments using celebrity and company-generated tweets. Journal of Marketing Communications. Routledge, 20(1-2), 129-146. doi: 10.1080/13527266.2013.797784.

Wu, J., Li, K.J. and Liu, J.S., 2018. Bayesian Inference for Assessing Effects of Email Marketing Campaigns. Journal of Business \& Economic Statistics, 36(2), 253-266. doi: 10.1080/07350015.2016.1141096.

Yoo, C.Y., Kim, K. and Stout, P.A., 2004. Assessing the Effects of Animation in Online Banner Advertising: Hierarchy of Effects Model. Journal of Interactive Advertising, 4(2), 49-60. doi: 10.1080/15252019.2004.10722087. 